
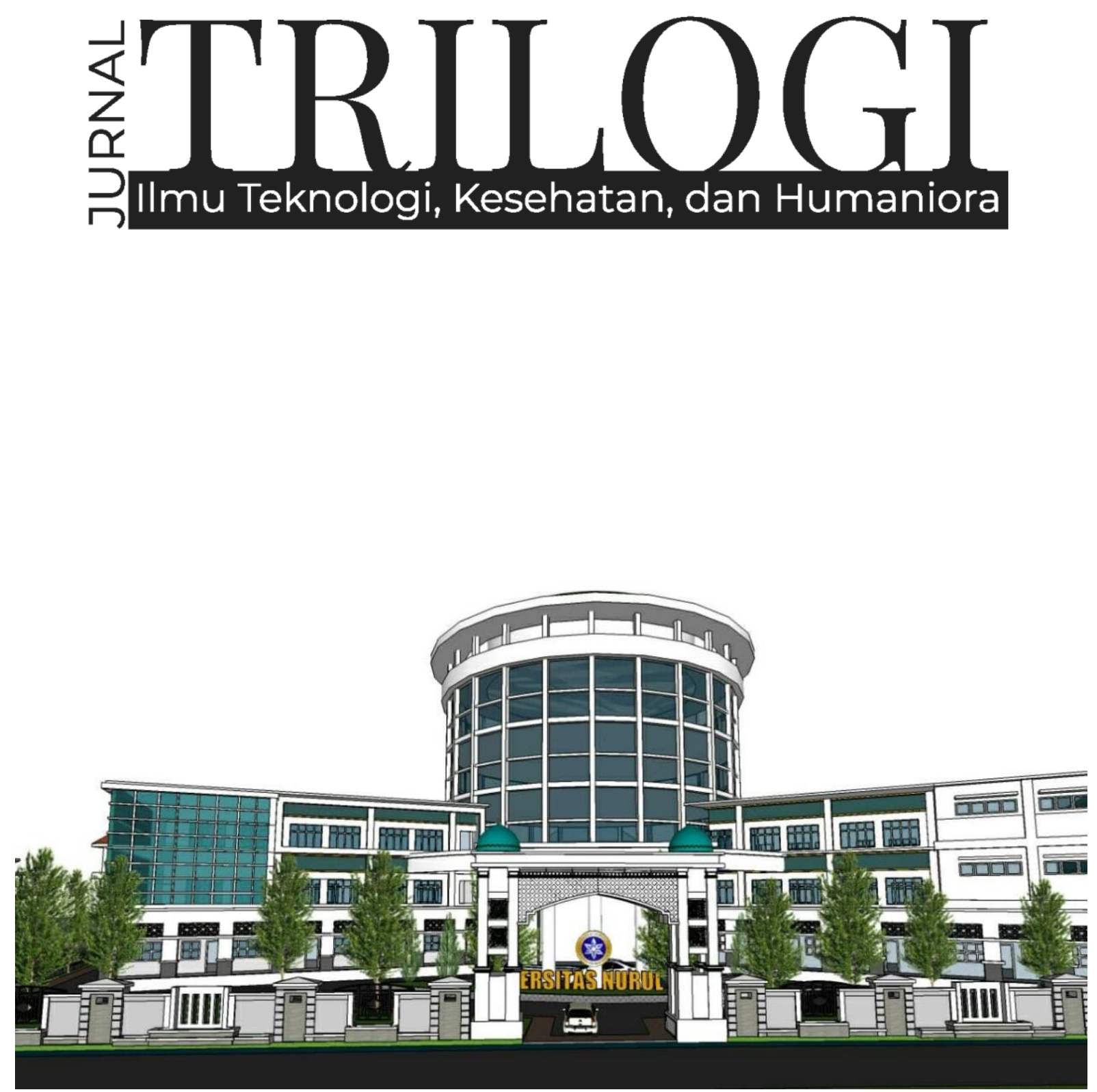

PENGEMBANGAN PENDIDIKAN DAN EKONOMI PESANTREN DI MASA PANDEMI COVID-19 


\section{犃BUOGI}

Vol. 2, No. 2, 2021

Editor in Chief

Achmad Fawaid, (SCOPUS ID: 57214837323)

\section{Managing Editors}

Hasan Baharun, (ID SCOPUS : 57200983602)

Sugiono Sugiono, (SCOPUS ID : 57199578160)

Ismail Marzuki, (SCOPUS ID: 57201500245

Subhan Rachman, (SCOPUS ID: 57192937912)

Nurul Huda, (SINTA ID: 6119615)

Syamsuri, (SINTA ID: 6116825)

Ridhatullah Assya'bani, (SINTA ID: 6200862)

\section{Peer Reviewers}

Miftahul Huda, (SINTA ID: 6171566), University of Antwerp, Belgium

Achmad Naufal Irsyadi, (SINTA ID: 6704870), Universitas Nurul Jadid, Indonesia

Gulpi Qorik Oktagalu P., (SINTA ID: 5982074) Universitas Nurul Jadid Probolinggo, Indonesia Hozairi, (SINTA ID: 166198), Universitas Islam Madura, Indonesia

Nur Hamid, (SINTA ID : 6744813), Univeristas Nurul Jadid Probolinggo, Indonesia Zainal Munir, (SINTA ID: 6672512), Universitas Nurul Jadid Probolinggo, Indonesia Sri Astutik Andayani, (SINTA ID: 6172559), Universitas Nurul Jadid Probolinggo, Indonesia Sukamto Sukamto, (SINTA ID: 5979034), Universitas Widya Gama Malang, Indonesia Deny Utomo, (SINTA ID: 6016108), Universitas Yudharta Pasuruan, Indonesia Fariz Alnizar, (SCOPUS ID: 6659824), UNUSIA Jakarta, Indonesia

Fuad Rahman, (SCOPUS ID: 57201474778), UIN Sulthan Thaha Saifuddin Jambi, Indonesia Saifuddin Zuhri Qudsy, (SCOPUS ID: 57213595165), UIN Sunan Kalijaga Yogyakarta, Indonesia Akhmad Anwar Dani, (SINTA ID: 14305), IAIN Surakarta, Indonesia

Maufur Maufur, (SINTA ID: 5989329), IAIN Kediri, Indonesia

Siti Mahmudah Noorhayati, (SINTA ID: 6726997), IAIN La Roiba Bogor, Indonesia Busro Busro, (SCOPUS ID: 57205022652), UIN Sunan Gunung Djati Bandung, Indonesia Akmal Mundiri, (SCOPUS ID: 57205059378), UNUJA Probolinggo, Indonesia

\section{Section Editor}

Ahmad Zubaidi, Universitas Nurul Jadid, Probolinggo, Indonesia 
TRILOGI: Jurnal IImu Teknologi, Kesehatan, dan Humaniora is a peer-reviewed journal, open-access journal which publishes original articles on various issues within technology, health, and social humanities, which include but are not limited to newrenewable energy, food-agriculture, health-pharmacy, transportation, informationcommunication technology, advanced-materials, maritime-infrastructre, social-artseducation, and religious studies based on academic and scientific research.

TRILOGI: Jurnal IImu Teknologi, Kesehatan, dan Humaniora seeks to publish a balanced mix of theoretical or empirical articles, case studies, review papers, comparative studies, exploratory papers, and book reviews. All accepted manuscripts will be possibly published both online and in printed forms.

Editorial Office:

TRILOGI: Jurnal IImu Teknologi, Kesehatan, dan Humaniora Lembaga Penerbitan, Penelitian, dan Pengabdian kepada Masyarakat (LP3M) Universitas Nurul Jadid, Paiton, Probolinggo, Jawa Timur, Indonesia 67291.

Phone: 088830 77077, Hp: 082318007953

Email: jurnal.trilogi@gmail.com

Website: https://ejournal.unuja.ac.id/index.php/trilogi/index 


\section{Tables of Content}

71-76

Pengaruh Metode Pembelajaran Daring dengan Aplikasi Google Classroom terhadap Hasil Belajar Siswa Madrasah Ibtidaiyah Nurul Mun'im Paiton Probolinggo

Feriska Listrianti, Lailatul Munawwaroh, Sayyidatul Arifa, Siti Aisyah

77-84

Inklusivitas dan Responsivitas Pesantren dalam Penanganan Pandemi Covid 19: Telaah Hidden Curriculum Pembelajaran di Pondok Pesantren Nurul Jadid

Zakiyah BZ, Uswatun Hasnah, Nafistur Rahmah

84-94

Integrasi Kurikulum Madrasah Diniyah dengan Lembaga Formal dalam Meningkatkan Mutu Lulusan di Sekolah Menengah Pertama (SMP) Nurul Jadid Paiton Probolinggo

Abdurrahman, Ika Fitri Anwar, Sofiya Mauliza, Nadya Afkarina

95-104

Some Issues on Time Deposit Financing: An Islamic Perspective on Mudharabah Agreement at Baitul Maal wa Tamwil (BMT) NU in Randuagung Lumajang

Saifuddin, Abdul Hafid, Hengki Wahyu Pratama

$105-110$

Analisis Pengembangan Potensi Ekonomi Keluarga melalui Unit Usaha Kapuk

Fahrudin, Iis Sa'diyah, Rizaldi Chandra Gunawan

111-117

Penguatan Ekonomi Pesantren melalui Pengembangan Ekonomi Masyarakat Pesisir: Pelajaran dari Pondok Pesantren Nurul Jadid Paiton Probolinggo

Achmad Febrianto, Muhammad Habibullah, Aksal Ilhamsyah

118-125

Prevensi Perilaku Konsumtif Persepektif Abraham Maslow dan Tri Logi Santri

Muhammad Syaiful Suib, Habibatur Rizkiyah, Fitria Nur Ain 
$126-136$

Manajemen Pengembangan Kurikulum Berorientasi pada Pembentukan Karakter

Moh Rifa'i, Fatimah Al Zahra, Abdurrahman Abdurrahman, Mukhlisin Saad

137-147

Home Industry, Kaderisasi, dan Santripreneur

Muh Hamzah, Aprilinda Dwi Kurniawati, Husnul Khotimah

148-157

Rancangan Pengelolaan Nirsampah Mandiri Skala Lembaga Pendidikan

Tirmidi, Eril Sinta Nuriyah, Rofi'ah

158-166

Parents' Knowledge and Commitment To Stimulate Child Development

Lailatul Fitriyah, Nurul Islamiyah, Auliya' Fatahillah

167-172

Implementasi Pembelajaran Akhlak Berbasis Multikultural pada Masa Pandemi di Madrasah Tsanawiyah Nurul Jadid Paiton Probolinggo

Abdullah, Yusrolana, Nur Laily

$173-183$

Implementasi Evaluasi Pembelajaran Daring (Online) melalui Home Visit

Moch Tohet, Moh. Bagus Abdillah, Adam Hakim Al Rizki

184-192

Efektivitas Pembelajaran Luring pada Mata Pelajaran Matematika selama Pandemi Covid-19

Zaenol Fajri, Sukron Junaidi, Hamdani Alfarisi 
P-ISSN: 2774-4574; E-ISSN: 2774-4582

TRILOGI, 2(2), Mei-Agustus 2021 (137-147) @2021 Lembaga Penerbitan, Penelitian, dan Pengabdian kepada Masyarakat (LP3M) Universitas Nurul Jadid Paiton Probolinggo

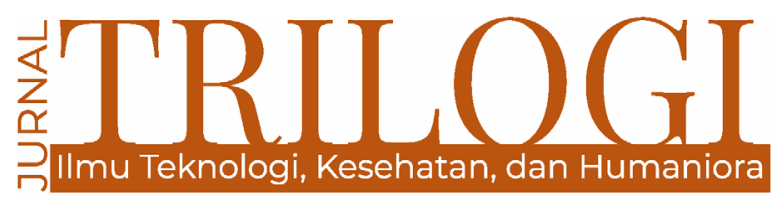

\title{
HOME INDUSTRY, KADERISASI, DAN SANTRIPRENEUR
}

\section{Muh. Hamzah}

Universitas Nurul Jadid, Probolinggo

hamzah.stikesnj@gmail.com

\section{Aprilinda Dwi Kurniawati}

Universitas Nurul Jadid, Probolinggo

alindadwik2000@gmail.com

\section{Husnul Khotimah}

Universitas Nurul Jadid, Probolinggo

husnulk532@gmail.com

\begin{abstract}
This study aims to explain the importance of pesantren as a container of the formation of cadres of the people not only in the field of religion, but also in the economic field. Islamic boarding schools do not only teach santri about Islamic sciences, but also teach them to enterpreneurship. Home Industry is present in response to sustainable economic problems. This study used the Field Research approach at PP Nurul Jadid, the Al-Mawaddah region. Data collection methods use interview and observation techniques. The results showed that Islamic boarding schools were able to provide great opportunities for the santri to be talented entrepreneurs with the business of home industrial bakery in the al-Mawaddah region. Marketing systems carried out locally and non-local transactions. By setting prices ranging from IDR 2000 to IDR 5,000 per bread, this Home Industry is able to increase turnover of Islamic boarding schools. The Bakery's business among Santri Al-Mawaddah was able to foster the provision of entrepreneurs when they plunged into the world of society, so they were able to be santri entrepreneurs.
\end{abstract}

Keywords: Home Industry; Regeneration; Santripreneur; Nurul Jadid 


\begin{abstract}
Abstrak
Penelitian ini bertujuan untuk menjelaskan urgensi pesantren sebagai wadah pembentukan kaderisasi umat tidak hanya di bidang agama, melainkan juga di bidang ekonomi. Pesantren tidak hanya mengajarkan santri ihwal ilmu keislaman, namun juga mengajarkan mereka melakukan enterpreneurship. Home industry hadir sebagai jawaban dari permasalahan ekonomi berkelanjutan. Penelitian ini menggunakan pendekatan field research di PP Nurul jadid wilayah Al-Mawaddah. Metode pengumpulan data menggunakan teknik wawancara dan observasi. Hasil penelitian menunjukkan bahwa pesantren mampu memberikan peluang besar terhadap diri para santri untuk dapat berbakat entrepreneur dengan usaha home industri bakery di Wilayah AlMawaddah. Sistem pemasaran yang dilakukan berbasis transaksi lokal dan non-lokal. Dengan mematok harga berkisar Rp 2000-Rp 5000 per roti, home industry ini mampu meningkatkan omzet terhadap devisa pesantren. Hadirnya usaha bakery bagi santri Al-Mawaddah mampu menumbuhkan bekal usaha entrepreneur ketika terjun kedalam dunia masyarakat, sehingga pada saat mampu membentuk santri-santri berjiwa entrepreneur.
\end{abstract}

Kata kunci: Home Industry; Kaderisasi; Santripreneur; Nurul Jadid

\section{Pendahuluan}

Pesantren dalam perkembangannya merupakan wahana khazanah yang sangat khas di Indonesia dalam mencetak kader-kader bangsa dengan sikap religiusitas dan intelektualitas. Selain memiliki keunikan tersendiri didalam memformulasikan nilai-nilai Islam, metode kearifan lokal dan barat didalam proses seni belajar mengajar, pesantren juga dipandang mampu mendidik jiwa-jiwa yang bisa mengexpose generasi pembentuk industri untuk menyelamatkan kehidupan dunia. Seperti halnya pembentukan kader kewirausahaan terhadap jiwa santri yang tengah menjadi hal baru dalam teka-teki kehidupan bernegara. Pondok pesantren sudah banyak diakui sebagai sebuah "institusi budaya" lahir atas dasar prakarsa dan inisiatif masyarakat. Adanya pondok pesantren sudah sangat terbukti memiliki peran yang sangat besar dalam sejarah perjuangan bangsa Indonesia.

Eksistensi pesantren tidak bisa dipisahkan dari perkembangan aktual pesantren dalam proses modernisasi. Beberapa ahli peneliti telah menegaskan bahwa tradisi pesantren sejak abad ke 20 sampai abad 21, yakni masa transisi peradaban Islamisasi kemodenisasi pembangunan peradaban Islam nusantara. Pondok pesantren didalam peradaban Islam nusantara terlahir diantara kuatnya identitas dan dinamika. Mengadopsi aspek-aspek positif suatu peradaban yang mampu menjadi mobilitas kaderisasi bangsa pembentuk jiwa entrepreneurship.

Pesantren sebagai sebuah pembangunan perekonomian yang mampu membangun pertumbuhan dan kesejahteraan perekonomian suatu bangsa. Namun, Indonesia tengah dihadapkan dengan problema yang sangat kompleks dalam problem pembangunan ekonomi, yang berdampak kepada munculnya ketidakseimbangan suatu perekonomian diberbagai sektor. Hal tersebut dikarenakan sebab adanya ketidakmampuan pembangunan dalam menyerap potensi perekonomian masyarakat, termasuk angkatan kerja sebagai kontributor bagi tercepatnya pertumbuhan dan kesejahteraan perekonomian dimasyarakat. Peran pesantren sebagai penyeimbang yang sangat dianggap mampu menjadi tonggak utama dalam sektor pembangunan. Lahirnya generasi yang berpotensi entrepreneur diharapkan dapat membuka lapangan usaha baru dalam memperbaiki tatanan kemasyarakatan.

Pondok pesantren mempunyai pengaruh yang sangat besar dan potensi yang sangat tinggi dalam mendukung adanya implementasi revolusi home industri keempat di Indonesia. Dimana langkah pertama prioritas nasional yang perlu dijalankan ialah dengan memberdayakan usaha mikro, kecil, dan menengah (UMKM). Menurut Menteri Perindustrian Airlangga Hartarto memaparkan bahwa usaha mendorong pertumbuhan perekonomian masyarakat ialah dengan cara mendirikan koperasi, mengembangkan berbagai unit usaha baik skala kecil maupun menengah inkubator bisnis. Dalam hal ini, kegiatan digencarkan dengan melakukan program penumbuhan wirausaha home industri baru dan pengembangan unit usaha home industri dilingkup pesantren yang dikenal dengan program santripreneur.

Dalam konsep implementasi santripreneur, terdapat dua pola penumbuhan wirausaha 
industri baru dalam pengembangan unit industri dipesantren, yaitu santri berindustri dan santri berkreasi. Adapun kemanfaatan yang didapat mendorong unit industri tersebut menjadi tempat magang para sumber daya insani dilingkungan pesantren. Sedangkan, pola santri berkreasi merupakan langkah pertama program kegiatan pelatihan dan pendampingan dalam proses mengembangkan potensi kreatif santri dan alumni yang terpilih dari berbagai pesantren untuk bisa menjadi seseorang yang profesional dibidang seni visual dan multimedia sesuai dengan standar industri di zaman sekarang.

Home industri di zaman sekarang memiliki eksistensi tersendiri sebagai penanggulangan problematika ekonomi yang semakin melilit dalam kehidupan masyarakat, banyak dari sebagian masyarakat mengeluh karena tidak terpenuhinya sandang pangan. Bahkan sampai sekarang, maraknya problematika dalam berkeluarga akibat faktor ekonomi semakin tidak terelakkan. Dengan hadirnya home industri memberikan pengaruh besar terhadap kehidupan perekonomian masyarakat sebagai bentuk responsive zaman dalam menjalankan kegiatan pencegahan terhadap permasalahan sosial ekonomi.

Eksistensi pesantren dalam mengakomodasi bentuk wirausaha santri dapat dikatakan sebagai home industri kedua. Hal ini dikarenakan bahwa pesantren merupakan pendidikan alternatif dan bukan merupakan pilihan utama, akan tetapi pesantren memiliki potensi yang akan mampu bangkit menepis stigma negatif dengan keinginan yang kuat, kemampuannya dalam bekerjasama dengan masyarakat untuk mengerjakan program pemberdayaan yang berhasil memcetak sekelompok wirausaha dan home industri.

Pada sisi lain, keunikan home industri yang terjadi pada pesantren lama yang hadir dengan "wajah baru", "elitis", "modern", juga mempunyai public-trust yang akuntabel. Muncul pula, beberapa keunikan home industri yang terjadi pada pesantren baru yang menampilkan orientasi juga pencitraan baru (image building). Keduanya mempunyai segmen pasar masyarakat (stakeholder) yang berbeda-beda, namun jika keduanya bersinergi, maka pada ujungnya akan mampu memberikan kontribusi real dan signifikan pada peningkatan kualitas hidup masyarakat muslim dan bangsa Indonesia (Basyit, 2017).

Pondok pesantren telah membuktikan tentang eksistensi dan berkontribusi menjadi dinamisator dalam setiap proses perkembangan, perjuangan, dan pembangunan suatu bangsa. Kontribusinya, tidak hanya sebatas lembaga pendidikan, namun juga sebagai lembaga perjuangan, sosial, ekonomi, keagamaan, budaya, dakwa dan juga lembaga kader. Adanya lembaga kader merupakan seseorang yang terpilih atau orang yang pantas diantara sekian banyak orang yang menjadi penggerak juga pengemban suatu misi organisasi. Kader disini merupakan bentuk perjuangan generasi sebelumnya sehingga dapat membenahi struktur yang ada dalam sebuah sistem. Pengkaderan yang berada dibawah pesantren merupakan sebuah sistem. Kader dan kaderisasi pesantren merupakan sebuah rangkaian dari banyaknya komponen yang saling berkaitan dan membentuk suatu totalitas. Dalam hal ini, kaderisasi pesantren bergerak di dalam bidang usaha home industri memiliki program pembuatan bahan mentah atau barang setengah jadi menjadi barang yang memiliki nilai tambah dan bermutu tinggi dalam memperoleh keuntungan. Hasil dari usaha home industri tidak hanya berbentuk barang tetapi juga berupa jasa. Pada umumnya home industri tergolong sektor informal yang memproduksi secara unik terkait dengan kearifan lokal seperti halnya pesantren. Home industri yang berada di naungan pesantren bergerak dalam skala kecil, dari tenaga kerja yang bukan profasional, modal yang kecil, dan produksi hanya secara musiman.

Potensi dan peran home industri dipesantren memiliki nilai yang sangat strategis dan signifikan dalam menyumbangkan sumbangsih dan perannya bagi peningkatan kemandirian dan partisipasi masyarakat. Dalam konteks pengembangan ekonomi umat, pesantren mempunyai peran sebagai agent of social change. Hal tersebut, terlihat setidaknya bagi sekelompok pesantren dan masyarakat disekitarnya, dengan dibentuknya komunitas wirausaha bersama antarpesantren ataupun antarpesantren dengan masyarakat.

\section{Metode}

Penelitian ini menggunakan jenis penelitian kualitatif dengan pendekatan deskriptif. Penelitian ini dilakukan mulai dari 05 Maret 2021 hingga 15 Maret 2021 dengan melibatkan 2 mahasiswa yang memiliki tugas dan fungsi yang telah ditentukan terlebih dahulu. Teknik analisis menggunakan analisis isi. Teknik pengumpulan data berdasarkan observasi, wawancara, dan dokumentasi. Objek yang dikaji berdasarkan keterhubungan usaha home industri dan santri di pesantren Nurul Jadid wilayah Al-Mawaddah. 


\section{Hasil dan Pembahasan}

\section{Eksistensi Home Industry di Pesantren}

Usaha home industri ialah usaha ekonomi produktif yang berdiri sendiri, yang dikelolah oleh perorangan atau badan usaha yang bukan milik anak perusahaan atau cabang perusahaan, dikuasai, atau merupakan bagian baik langsung maupun secara tidak langsung dari usaha menengah atau usaha besar, yang sudah memenuhi kriteria usaha kecil sebagaimana yang telah dijelaskan dalam UU No. 20 dan UU No. 21 tahun 2008 (Zuhri, 2013. Bahwa usaha home industri ialah milik WNI (Warga Negara Indonesia), yang berdiri sendiri, berafiliasi langsung maupun tidak langsung dengan usaha menengah ataupun besar dan berbentuk badan usaha perorangan, ataupun tidak berbadan hukum. Home industri dapat diartikan sebagai sebuah usaha rumah tangga, sebab merupakan usaha kecil yang di produksi dalam rumah.

Adapun peluang pengembangan dalam home industri kreatif sudah menyebar pada dunia pendidikan. Tidak luput juga dalam dunia pesantren. Banyak yang sudah ditemukan pesantren-pesantren yang telah mengembangkan home industri kreatif (Noviyanto, 2017). Home industri kreatif menjadikan sumber daya insani (SDI) sebagai modal utama dalam sebuah pengembangan yang berawal dari suatu gagasan, ide dan pemikiran. Kedepannya, sumber daya insani (SDI) mampu mengembangkan barang yang memiliki nilai rendah menjadi barang yang memiliki nilai tinggi dan berdedifikasi. Maka pengembangan home industri kreatif secara tidak langsung mengarahkan dan mencoba untuk bisa mencetak wirausaha santri (satripreneur) yang handal didalam berbagai bidang. Hal ini dapat di implementasikan baik berasal dari santriwan dan santriwati.

Kurang lebih dari 17 pesantren di Pulau Jawa yang mengembangkan mitra program pengembangan home industri kreatif. Di antaranya, pondok pesantren Arrisalah Ciamis misalnya telah berhasil mengembangkan dalam ekonomi dibidang perikanan. Pondok Pesantren Salafiyah Syafi'iyah Sukorejo berhasil dalam mengelola dibidang usaha butik, usaha air minum dan usaha percetakan. Pondok pesantren Darussalam Gontor secara mandiri sudah sukses dalam mengelola dibidang sektor riil, pertanian dan perkebunan. Pondok pesantren Sidogiri Pasuruan berhasil dibidang koperasi pondok pesantren (KOPONTREN), Baitul Mal Wattamwil, Bank Perkreditan Rakyat Syariah
(BPRS) dan berbagai sektor riil. Pondok pesantren Al-Amin Sumenep berhasil dalam mengelolah dibidang ekonomi berbasis kelautan dan Pondok pesantren Al-Ittifaq Rancabali Bandung sukses dalam mengelolah dibidang agribisnisnya (Falah, 2017). Sehingga Pondok pesantren tersebut mempunyai eksistensi legal dalam masyarakat yang bisa menyalurkan pengaruh tinggi terhadap perkembangan masa.

Contoh konkret pengembangan home industri kreatif yang berada dinaungan pondok pesantren Al-Ittifaq Rancabali Bandung didalam bidang agribisnisnya serta mengajak para santrinya dengan dibekali ilmu agama dan juga ilmu agribisnis. Kegiatan usaha yang dikelolah oleh pondok pesantren tersebut memiliki dampak ganda terhadap proses pendidikan, industri kreatif (olahan tangan), seperti roti, tahu susu, dan air botol mineral. Selain itu sebagai sarana pencukupan keperluan warga pesantren juga menekan biaya produksi sehingga hasil yang di produksi dapat memiliki nilai unggul kompetitif dan komparatif serta menjadi laboraturium sebagai penumbuh kembangnya jiwa mandiri dan wirausaha santri. Impact-nya tujuan pendidikan yang diharapkan oleh pondok pesantren AlIttifaq seperti mencetak santri yang berakhlakul karimah, mandiri serta berjiwa wirausaha dan mampu tercapai.

Peran home industri didalam sebuah sistem ekonomi selain juga menciptakan lapangan usaha sebagai bekal bagi para santri terutama santri perempuan, mampu meningkatkan dalam pola pendapatan, dan kesejahteraan dalam berumahtangga, selain itu, home industri mampu berperan sebagai perekat dan stabilitas sosial dalam mengurangi kesenjangan ekonomi dan sosial.

Dalam sosiologi ekonomi masyarakat yang di dalamnya terdapat sebuah proses dan pola interaksi sosial, didalam hubungannya dengan ekonomi. Hubungan dipandang dari pola saling pengaruh-mempengaruhi. Para santri sebagai sebuah realitas eksternal-objektif yang akan mengantarkan individu dalam mengelolah program ekonomi seperti apa yang boleh diproduksi, bagaimana proses memproduksinya, dan dimana tempat memproduksinya.

\section{Pemberdayaan Ekonomi Berbasis Kader}

Pondok pesantren telah menunjukkan peran yang penting bagi dinamika sosial dilevel lokal dan nasional. Adanya pesantren tidak hanya sebagai wahana dan sarana pendidikan Islam saja. 
Akan tetapi, juga merupakan sarana akselerasi perubahan dan mobiltas umat dan bangsa. Di dalam pondok pesantren, pesantren mengemban empat peran signifikan yaitu sebagai pendidikan Islam, dakwa Islam, pemberdayaan dan juga sebagai wahana kaderisasi.

Pesantren yang identik dengan ruh pendidikan Islam, identik pula di dalamnya mengkaji tentang hukum-hukum Islam, dan kini sudah berkembang mengikuti arus kontemporer dalam memberdayakan santri-santrinya.

Dewasa ini, kenyataan yang telah terjadi di dalam pondok pesantren yang mengemban kiprah dan peran. Fungsi sebagai lembaga keagamaan atau dakwa, tercermin dari pola pengajaran dan pendidikan ke Islaman yang diterapkan didalam pesantren. Fungsi sebagai lembaga pendidikan, tercermin dari pola jenjang pendidikan yang disediakan oleh pesantren, mulai dari pendidikan usia kanak-kanak sampai dengan pendidikan perguruan tinggi. Fungsi sebagai lembaga pengembangan santri atau kaderisasi, tercermin dari pola amal usaha yang dikembangkan pesantren pada bidang sosial ekonomi.

Persamaan antara kiprah dan peran pesantren dalam upaya menanamkan kemandirian ekonomi melalui pemberdayaan santri. Keberdayaan santri ditandai adanya kemandiriannya dapat dicapai melalui proses pemberdayaan santri. Keberdayaan santri dapat dicapai melalui partisipasi aktif santri yang difasilitasi dengan adanya pelaku pemberdayaan (Falah \& Zaki, 2017).

Oleh karena itu, dalam menumbuhkembangkan jiwa entrepreneur dalam mencetak wirausaha santri (santripreneur) tentu membutuhkan pihak tertentu, baik pemerintah, swasta ataupun individu. Pondok pesantren harus terus melangkah demi meningkatkan mutunya baik dalam pola kualitas keimanan dan kualitas perekonomian. Oleh sebab itu, pesantren harus terus menyalurkan ilmu tentang pendidikan Agama Islam dengan baik dan juga harus diiringi dengan ilmu pengetahuan yang luas, terutama keterampilan dalam mengelolah program perekonomian seperti pengembangan kewirausahaan yang meliputi bidang keterampilan seperti pembuatan produk sendiri, sehingga pesantren selain merupakan pusat pembinaan para santri didalam bidang keagamaan juga sebagai media pendidikan kewirausahaan yang nantinya diharapkan bisa mendorong kehidupan diri, keluarga dan masyarakat sekitar.

Secara historis, inisiatif didalam berbagai pesantren melakukan pemberdayaan santri dan masyarakat sudah muncul sejak era 1970-an.
Pesantren Muntilan contohnya dimasa itu dengan tokoh KH Imam Dja'far berperan aktif dalam program pengembangan santri dipesantren dan masyarakat didesa. Program tersebut kemudian melahirkan penghimpunan pengembangan pesantren dan masyarakat.

Adapun contoh konkret didalam pemberdayaan ekonomi. Bahwa, pondok pesantren Hidayatullah Surabaya berperan dalam memberdayakan masyarakat disekitarnya. Peran pesantren ditunjukkan dari beberapa program yang dikelolah oleh pihak pesantren dengan bertujuan dapat memberdayakan masyarakat disekitar pesantren.

Program pemberdayaan yang dikelolah pondok pesantren ialah dengan cara mengangkat atau merekrut tenaga kerja yang dibutuhkan oleh pondok pesantren dari masyarakat sekitar. Program lain yang dikelolah pondok pesantren ialah mengadakan pelatihan keterampilan menjahit bagi masyarakat sekitar, dengan sasaran ibu-ibu dan warga yang kurang mampu. Kerja sama antar masyarakat serkitapun dilakukan pondok pesantren dalam upaya pencukupan kebutuhan pondok pesantren dalam memproduksi seragam sekolah. Program kepedulian sosial bagi masyarakat sekitarpun rutin dilakukan pondok pesantren, seperti adanya kegiatan bakti sosial dan bazar murah bagi masyarakat sekitar menjelang bulan Ramadhan, serta penyaluran parcel lebaran dan pembagian daging qurban dengan sasaran prioritas adalah masyarakat sekitar pondok pesantren (Falah \& Zaki, 2017).

\section{Profil Singkat Wilayah Al-Mawaddah Pondok Pesantren Nurul Jadid Paiton Probolinggo}

Wilayah Al-mawaddah ialah merupakan wilayah (Asrama) yang berada dibawah naungan pondok pesantren Nurul Jadid sebagai tempat membina santriwati dari berbagai jenjang pendidikan mulai tingkat SLTP, SLTA, Mahasiswi dan Khorijat (santri yang tidak sekolah formal). Untuk lebih mengoptimalkan pembinaan dan pendidikan santri, wilayah Al-mawaddah telah melaksanakan pemetaaan dan pengelompokan didalam proses pembelajaran yang sesuai dengan minat bakat dan kecenderungan masing-masing santri, serta merupakan beberapa program khusus/unggulan. Masing-masing program ini mempunyai ketentuan, target dan out put tertentu, yang harus dicapai oleh santri sesuai dengan program keahlian pilihan masing-masing.

Dalam upaya mencetak santri yang berkualitas dan siap berkhidmah untuk agama, bangsa dan negara, Wilayah Al-Mawaddah juga telah 
melaksanakan pembinaan intensif untuk mengasah Leadership dan Managemen santri serta mengembangkan skill tertentu yang dapat menunjang kemampuan dan kiprahnya setelah kembali ke tengah-tengah masyarakat (Profil Al-Mawaddah, tth).

Dewasa ini, wilayah Al-mawaddah juga memiliki sumber daya insani (SDI) yang dinamakan dengan santriprenuership. Maka dari itu, diwilayah Al-mawaddah membuka usaha roti, usaha kuliner seta juga air mineral dan sebagainya. Bermodal keinginan wilayah Al-mawaddah tersebut terus melangkah maju ke realisasi usaha memproduksi roti.

Pilihan utama usaha home industri tidak terlepas dari likasi pondok pesantren yang terletak disekitar masyarakat, sehingga sumber daya insani (SDI) bisa mendukung dalam mengembangkan usaha home industri. Pemanfaatan sumber daya insani ini sudah direncanakan dengan baik melalui motivasi, wawasan serta kemampuan metodologis disamping aspek pendanaan dan perlengkapan lainnya. Kegiatan pemberdayaan didalam pesantren bertujuan untuk membina juga mengembangkan keterampilan dan kualitas para santri didalam pesantren untuk selanjutnya dapat membuat rencana usaha dan melaksanakan rencana usaha tersebut.

Adapun harapan wilayah Al-mawaddah ke depannya ialah agar supaya ada kader yang siap untuk meneruskan usaha produksi roti. Selain juga, dengan hadirnya usaha yang dikelolah oleh wilayah Al-mawaddah bisa lebih unggul dalam segala bidang, baik itu didalam bidang pendidikan, bidang kesejahteraan, bidang usaha maupun lainnya.

Jika fungsi utama membuat pesantren berkembang menjadi pusat studi keagamaan dan kemasyarakatan, maka fungsi lainnya menuntut pesantren menjadi pionir dalam program-program pengembangan umat itu sendiri. Pada posisi yang demikian pesantren sudah manghabiskan diri sebagai institusi pendidikan, dakwah sekaligus lembaga sosial-ekonomi. Peran tersebut tentu sangat penting mengingat adanya pesantren tidak dapat dipisahkan dengan masyarakat. Salah satu indikasinya letak pesantren selalu berada di tengah-tengah suatu komunitas masyarakat (Hafidh \& Badrudin, 2018).

\section{Pengkaderan dalam Ekonomi Pesantren Nurul Jadid}

Pondok pesantren Nurul Jadid mempunyai peran yang strategis dan sangat penting yaitu sebagai lembaga pendidikan sosial dan ekonomi untuk berinteraksi serta berwirausaha seperti diadakannya usaha home industri didalam pesantren. Usaha home industri pesantren sebagai community development dalam memajukan usaha ekonomi berdasarkan potensi dan kebersamaan santri serta lingkungannya dalam meningkatkan kesejahteraan dan kemandirian.

Dalam menumbuh kembangkan jiwa entrerpreneur dipondok pesantren Nurul Jadid sudah tampak jelas, dapat dilihat dengan diluncurkannya berbagai program dalam mengasah potensi SDMnya. Seperti program NJ Mart, pom bensin, industri kreatif (olahan tangan) semua itu dilakukan agar mutu keilmuan yang telah menjadi pokok utama pengelola pondok pesantren dapat benar-benar terealisasi didunia masyarakat pasca santriwansantriwati menyelesaikan pendidikan dilingkungan pesantren. Untuk melahirkan santri yang memiliki jiwa entrepreneur tersebut, tentu harus banyak dibekali dengan keterampilan hidup, sehingga mereka dapat mengembangkan keterampilanya agar menjadi lapangan usaha baik untuk dirinya sendiri maupun bagi orang lain.

Dalam hal ini, pelaksanaan pengkaderan ekonomi terhadap santri dilingkungan pondok pesantren Nurul Jadid ini nantinya dapat diharapkan dengan melahirkan out put santri yang memiliki daya kompetisi yang tinggi. Dengan bekal keterampilan yang diberikan, diharapkan mereka bisa lebih produktif dan mampu bersaing didunia kerja. Dengan ini, pesantren mengambil langkah tepat karena dapat membuktikan bahwa pondok pesantren Nurul Jadid terbilang menjadi bagian dari lembaga pendidikan yang berkualitas dan kompetitif.

Potensi ekonomi pesantren mepunyai nilai yang sangat strategis dan signifikan dalam menyumbangkan sumbangsih dan perannya demi meningkatnya keswadayaan, kemandirian, dan partisipasi kepada masyarakat. Dalam konteks pengembangan ekonomi pesantren, pondok pesantren Nurul Jadid berperan sebagai agent of social change, sekaligus berperan sebagai pelopor kebanggkitan ekonomi pesantren. Bahkan pesantren terbilang merupakan pihak yang menyambut hangat dalam pengembangan sektor usaha home industri bakery. Pada mulanya tentu masih dikerjakan dengan pengelolaan manajemen yang sangat sederhana. Akan tetapi, lambat laun usaha home industri bakery wilayah Al-mawaddah pondok pesantren Nurul Jadid berkembang menjadi perekonomian dilingkungan santri. Contoh konkret di pondok pesantren Salafiyah Syafi'iyah Sukorejo dalam mengelola 
di bidang usaha butik, usaha air minum mineral dan usaha percetakan.

Selain memberikan kontribusi berharga bagi pengembangan usaha home industri bakery dalam makna fisik. Misalnya, keterampilan pesantren juga dapat berandil besar dalam penggalakan entrepreneurship. Dilingkungan pesantren, para santri dididik menjadi insan yang memiliki sikap mandiri dan berjiwa entrepreneurship. Mereka semangat berusaha dan bekerja keras secara independent tanpa menggantungkan nasibnya kepada orang lain atau kepada lembaga pemerintah maupun swasta. Notabene para santri biasanya berkenan untuk bekerja apa saja, asal halal. Bahkan dari kalangan umum tidak pernah terdengar, seorang santri harus kebingungan mencari lowongan pekerjaan dan terpaksa jadi pengangguran.

Dengan beranggapan dasar bahwa tidak semua lulusan atau keluaran pondok pesantren akan menjadi ulama atau kiyai dalam memilih peluang pekerjaan dibidang agama, maka kemampuankemampuan lain seperti pendidikan keterampilan perlu disalurkan kepada santri, sebelum santri itu terjun ke tengah-tengah masyarakat yang sesungguhnya. Dipihak lain, untuk mendukung keberhasilan pembangunan maka diperlukan partisipasi semua pihak, termasuk pihak pondok pesantren sebagai suatu lembaga yang cukup berpengaruh ditengah-tengah masyarakat. Ini merupakan salah satu potensi yang dimiliki oleh pondok pesantren secara historis dan tradisi (Lugina, 2017).

Selain itu, pesantren juga berperan didalam lembaga produksi dan konsumsi. Pesantren sebagai lembaga produksi yang ditunjukkan dengan adanya penguasaan terhadap usaha home industri bakery, serta mempunyai sumber daya insani (SDI) dan peralatan yang memadai untuk memproses produksi yang akan dihasilkan dalam usaha home industri bakery, hal ini menunjukkan bahwa pesantren sebagai produsen dari masyarakat. Dalam hal ini, pesantren bergerak didalam bidang industri (kerajinan, kecil). Sehingga pesantren dipandang jelas sebagai produsen dalam bidang industri. Agar dapat melanjutkan eksistensinya dalam dunia usaha, maka pesantren harus terus berinovasi dalam mengembangkan produknya. Langkah awalnya ialah membuat faktor-faktor produksi yang efisiensi dimiliki dan kemudian mengembangkan diversifikasi produk dan tenaga kerja. Dengan demikian akan memunculkan efisiensi ekonomi. Sedangkan efisiensi ekonomi mengacu pada nilai out put yang dikeluarkan, atau nilai sumber daya (faktor-faktor produksi) yang digunakan dalam memproduksi output-output tersebut. Pengukuran efisiensi ekonomis mensyaratkan nilai-nilai yang ditempatkan pada komoditi.

\section{Pesantren dan Home Industri: Kaderisasi Entrepreneur di Indonesia}

Secara harfiah kata pondok berasal dari bahasa arab "punduk" yang berarti tempat tidur, wisma, atau hotel sederhana. Adapun dalam makna bahasa Indonesia kata pondok menekankan kesederhanaan pada bangunan beserta isinya, dalam makna lainnya juga berarti kamar, gubuk, dan rumah kecil. Secara realitasnya pondok meupakan penampungan bagi penimba ilmu (santri) yang jauh dari kampung halamannya (Manfred, 1989). Di jawa atau sunda pondok lebih dikenal dengan panggilan pesantren atau pondok pesantren, sedangkan di daerah Aceh lebih dikenal denagn sebutan Dayah arau rangkang atau meunasah. Di Minangkabau dikenal dengan sebutan surau (Mas'ud, 2002).

Pesantren merupakan sebagai sistem pendidikan unik dan sangat khas yang ada di Indonesia, dengan mayoritas penduduknya beragama islam. Dikenal sangat khas karena pondok pesantren hanya berkembang pesat di Indonesia dan merupakan satu-satunya instansi formal yang dimiliki Negara Indonesia tidak pada Negara lain. Disebut unik karena pesantren memiliki karakteristik lengkap yang berbeda dengan sekolah-sekolah umum, seperti halnya terdapat kiai, santri, pondok, kitab klasik, dan masjid.

Di pesantren, dalam program penguatan dan pengembangan potensi ekonomi pesantren secara umum merupakan replikasi atau alasan keberhasilan pesantren dalam mengembangkan kegiatan ekonomi bagi pesantren dan masyarakat yang memiliki potensi ekonomi, sumber daya insani (SDI) dan mendapat dukungan dari pimpinan pesantren yang tinggi. Pendampingan di mulai dari kegiatan orientasi berbasis praktek, menyediakan dana pengembangan ekonomi, dan proses transmisi atau replikasi dan bantuan pengawasan. Dengan adanya program penguatan dan pengembangan potensi ekonomi pesantren, telah menjadi ketentuan bagi pesantren untuk selalu dapat mengembangkan potensi yang ada di pondok pesantren kepada santriwan-santriwati dan masyarakat disekitarnya.

Dengan adanya pengembangan ekonomi, Pesantren merupakan bagian lembaga yang banyak diminati masyarakat yang didalamnya tidak hanya kegiatan yang bersifat rohani. Tetapi, 
terdapat pengembangan, pembinaan, serta penguatan potensi ekonomi pesantren. Terkait dengan adanya penguatan dan pengembangan lembaga ekonomi dipesantren, diperlukan upaya untuk meningkatkan taraf (ekonomi) masyarakat sekitar sebagai bagian dari perjuangan melawan kemiskinan (jihad) mengingat umat Islam di Indonesia sampai sekarang masih tersisihkan.

Perkembangan masyarakat saat ini membutuhkan pembentukan siswa yang dilakukan secara seimbang antara nilai-nilai, sikap, pengetahuan, kecerdasan dan keterampilan, bertujuan untuk memberi kemampuan untuk berkomunikasi dengan masyarakat luas serta dapat meningkatkan kesadaran terhadap lingkungan alam. Pendidikan yang demikian itu diharapkan dapat membantu dengan rangka pembudayaan dalam mempersiapkan masyarakat guna melakukan suatu pekerjaan yang merupakan mata pencahariannya, dan sangat berguna terhadap masyarakat serta mampu menyesuaikan diri secara konstruktif dalam perubahan-perubahan yang terjadi disekitarnya. Untuk memenuhi tuntutan dari pembinaan dan perkembangan bangsa yang begitu luas dan berat, kini pemerintah dan masyarakat selalu berusaha memobilisasi semua sumber yang ada kemungkin yang ada sehingga pendidikan secara keseluruhan mampu mengatasi berbagai problem yang dihadapi oleh masyarakat dan negara.

Dalam upaya memobilisasi semua sumber daya yang tersedia dibidang pendidikan dalam menyelesaikan berbagai problem tersebut, maka eksistensi pondok pesantren akan lebih disorot. Karena masyarakat dan pemerintah manghadapkan pondok pesantren yang memiliki potensi besar kedalam bidang pendidikan, keagamaan dan sosial. Partisipanya juga dapat ditingkatkan secara aktif dalam konteks pemberdayaan dan pengembangan masyarakat. Realitanya pesantren telah dianggap mampu menjadi suatu lembaga yang kuat untuk melegitimasi otoritas dan kiyai. Dengan pesantren pula kiyai mampu membangun dan mengembangkan jaringan kekuasaannya dengan masyarakat luar (Lugina, 2017).

Home berarti rumah, tempat tinggal, atau kampung halaman. Sedangkan industri, dinamakan sebagai kerajinan, usaha pembentukan produk. Home industri berarti usaha kecil yang terpusat pada rumah (Zuhri, 2013). Home industri merupakan kegiatan bisnis yang dikerjakan dirumah dengan berbagai strategi dan mekanisme pemasaran, baik berupa usaha jasa, kantor hingga perdagangan (Ulum, t.th). Sumodiningrat mengemukakan home industri memiliki ciri utama yakni: pertama, tidak terpisahnya kedudukan pemilik dengan manajerial; kedua, terpusat pada tenaga sendiri; ketiga, un-bankble beralih pada modal pribadi; keempat, mayoritas legal. Sedangkan menurut Bank Indonesia ciri utamanya, yakani: 1). Sumber kepemilikan atas nama keluarga dan pribadi 2). Teknologi sederhan adan padat karya 3). Rata-rata tingkat keterampilan dan pendidikan rendah 3). Tidak berpajak. Home industri dalam pedesaan biasanya memnafaatkan Sumber Daya Alam yang ada dan menggunakan teknologi yang ada. Hadirnya home industri bagi masyarakat pribumi dalam menyumbangkan sumbangsih besar terhadap pendapatan masyarakat.

Dewasa ini, usaha home industri ini merambah hampir keseluruh lapisan masyarakat, maka dengan hadirnya usaha home industri bisa merubah taraf perekonomian yang kurang stabil. Pengembangan ekonomi pesantren dihadapkan pada upaya meningkatkan standar hidup dan kesejahteraan pesantren dan masyarakat dalam bentuk program kegiatan usaha bersama. Inilah yang menjadi ciri khas pesantren yang selalu bisa mandiri dalam kegiatan keagamaan Islam di tengah-tengah masyarakat. Moh. Idil Ghufron mengatakan bahwa sesuai dengan pidato Presiden Joko Widodo sekitar pada tahun 2017 berkata "Industri kerajinan, industri kreatif di Indonesia telah tumbuh dengan sangat cepatnya, tumbuh dengan menakjubkan. Oleh karna itu saya meyakini, masa depan Indonesia akan ada di industri kerajinan atau industri kreatif. Ini yang saya yakini" (Ghufron, 2019). Menyimpulkan tentang pernyataan dari Presiden Joko Widodo bahwa, industri kreatif (olahan tangan) merupakan aset paling penting dalam perekonomian nasional yang perlu diperhatikan, dipelajari dan dikembangkan oleh masyarakat Indonesia dalam rangka agar masyarakat ikut berpartisipasi dalam memajukan ekonomi di Indonesia.

\section{Kaderisasi Santripreneur dalam Pesantren: Kajian Usaha Bakery Santri Putri Al-Mawaddah}

Dalam perkembangannya eksistensi pesantren menjadi sesuatu yang berpengaruh besar terhadap pembentukan manusia yang aqiilin, muttaqin, dan Sholihin. Hal tersebut menjadi indicator pesantren bahwa pada hakikatnya pesantren bukanlah sarana peribadatan namun juga sebagai pencetak kader sumber daya insani unggul dalam segala bidang ilmu, termasuk ilmu 
tentang berwirausaha. Salah satu bentuk usaha dalam pondok pesantren yang dapat terlihat eksistensinya ialah usaha home industri bakery di PP.Nurul Jadid wilayah Al-Mawaddah.

Dengan kultur khasnya, kombinasi antara minat-bakat santri dan kultur pesantren bisa menghasilkan wirausaha-wirausaha dalam bidang home industri kreatif. Salah satu jenis home industri kreatif yang paling mudah dikembangkan demi melahirkan santripreneur-santripreneur ialah home industri bakery (Abbas, dkk, 2019). Ni Putu Kiki Vrashinta Dewi mengatakan bahwa sesuai dengan Ariessiana pada sekitar tahun 2009 bakery merupakan salah satu bentuk alternatif makanan jadi yang cukup diminati konsumen karena tersedia beraneka macam varian rasa (Dewi, dkk, 2015). Yang digunakan diantaranya seperti rasa cokelat, rasa pisang, rasa bluberry, rasa strawberry, pizza, dan sosis. Wilayah Almawaddah selalu mencari inovasi baru dalam meningkatkan minat para konsumen untuk bisa unggul dalam industri kreatif.

Awal hadirnya usaha home industri bakery wilyah Al-mawaddah belum terkait secara langsung, baik secara kelembagaan maupun permodalan dengan pesantren. Akan tetapi seiring dengan berjalannya program usaha home industri bakery, dengan memperbaiki sistem keorganisasian sejalan dengan dukungan anggota dan pesantren, maka disepakati seluruh simpanan dari usaha home industri bakery wilayah Al-mawaddah merupakan salah satu kekayaan pesantren. Saat itulah laba yang diperoleh dari penghasilan pendapatan usaha home industri bakery digunakan untuk kemaslahatan pesantren.

Wilayah Al-mawaddah memiliki toko camilan dan pakaian. Tetapi sayangnya, semua produksinya ialah produksi dari luar wilayah Almawaddah. Dengan hadirnya program kegiatan pengembangan kewirausahaan santripreneur ini, diharapkan barang yang dijual ditoko wilayah Al-mawaddah ialah produk hasil karya internal para santri. Selain bisa meningkatkan ekonomi wilayah Al-mawaddah, program wirausaha ini juga diharapkan bisa menjadi tambahan keahlian para santri ketika mereka sudah pulang ke kampung halamannya.

Wilayah Al-mawaddah merupakan bagian dari pondok pesantren Nurul Jadid Paiton Probolinggo. Yang memiliki IKM (Industri Kecil Menengah) dan sudah terkenal tentang cara pembuatan industri olahan tangan ke wilayah-wilayah lain yang berada di naungan pesantren Nurul Jadid, home industri kreatif yang akan dihasilkan oleh olahan tangan santri Al-mawaddah, seperti roti, kuliner, air mineral dan sebagainya.

Berangkat dari modal keinginan wilayah Almawaddah agar semua sumber daya insani (SDI) Al-mawaddah dapat dimanfaatkan tenaga, ide dan fikirannya yang disebut dengan santripreneur dan kaderisasi, guna mengoptimalkan kinerja yang berjalan dengan modal keinginan tersebut bisa melangkah lebih jauh ke arah realisasi industri kreatif (olahan tangan). Dalam hal ini Al-Mawaddah berusaha memproduksi inovasi baru berupa kuliner yang digemari para santri khususnya pada lingkup Nurul Jadid sendiri yakni bakery. Varian rasa bakery yang disajikan diantaranya seperti rasa cokelat, rasa pisang, rasa bluberry, rasa strawberry, pizza, dan sosis.

Harapan wilayah Al-mawaddah dalam usaha home industri kedepannya agar kader yang telah dipercaya dapat mengembangkan juga melanjutkan usaha home industri kreatif yang memproduksi usaha bakery. Sistem pemasaran yang dilakukan berbasis transaksi lokal dan non lokal. Dengan mematok harga berkisar Rp 2000Rp 5000 mampu memberikan omset terhadap devisa pesantren. Setiap memproduksi bakery dari 6-8 kg perkiraan bisa menghabiskan sebanyak 250 bakery setiap harinya. Bahan mentah yang biasa digunakan dalam pembuatan bakery seperti tepung, telur, gula, mentega, maizena, perasa buah, dll. Diolah dengan menggunakan alat sederhana dan dikemas dengan kemasan semenarik mungkin mampu memberikan daya saing terhadap produk lainnya (Interview Pengurus, 2020). Adapun tabel kandungan gizi bakery /100 gr ialah sebagai berikut:

\section{Tabel. Komposisi Gizi Roti Tawar dan Roti} Rasa per 100gr Bahan Zat Gizi.

\begin{tabular}{ccc}
\hline Zat Gizi & Roti Tawar & Roti Rasa \\
\hline Energi (Kkl) & 248,00 & 249,00 \\
\hline Protein $(\mathrm{g})$ & 8,00 & 7,90 \\
\hline Lemak (g) & 1,20 & 1,50 \\
\hline Karbohidrat (g) & 50,00 & 49,70 \\
\hline Kalsium (mg) & 10,00 & 20,00 \\
\hline Fosfor (mg) & 95,00 & 140,00 \\
\hline Besi (mg) & 1,50 & 2,50 \\
\hline Vitamin A (SI) & 0,00 & 0,00 \\
\hline Vitamin B1 (mg) & 0,10 & 0,15 \\
\hline Vitamin C (mg) & 0,00 & 0,00 \\
\hline Air (g) & 40,00 & 40,00 \\
\hline
\end{tabular}


Berdasarkan tabel diatas bahwasanya kadungan gizi roti tiap $100 \mathrm{gr}$ mampu memberi 100 kandungan kalori yang meliputi kandungan Energi (Kkl) sebanyak 248,00 dan 249,00, Protein ( $\mathrm{g}$ ) sebanyak 8,00 dan 7,90, Lemak (g) sebanyak 1,20 dan 1,50 , Karbohidrat $(\mathrm{g})$ sebanyak 50,00 dan 49,70, Kalsium (mg) sebanyak 10,00 dan 20,00, Fosfor (mg) sebanyak 95,00 dan 140,00, Besi (mg) sebanyak 1,50 dan 2,50, Vitamin A (SI) sebanyak 0,00 dan 0,00, Vitamin B1 (mg) sebanyak 0,10 dan 0,15 , Vitamin $C(\mathrm{mg})$ sebanyak 0,00 dan 0,00, Air (g) sebanyak 40,00 dan 40,00 yang dibutuhkan oleh tubuh. Persediaan roti yang disajikan oleh Al-Mawaddah mampu memberikan energi, kalori, vitamin pada tubuh terutama pada santri.

Sistem pemasarannya menggunakan sistem Go Food yang di distribusikan cara lokal dan non local. Untuk daerah lokal mencakup wilayahwilayah Nurul Jadid baik putra maupun putri seperti wilayah Fathimatuzzahro', An-Nafi'iyah, AzZainiyah, Al-hasyimiyah, Ar-Rumi, Nurus-Shobah, dll. Dan untuk daerah non lokal mencakup daerah luar pesantren seperti pada daerah Paiton, Tanjung, Kraksaan, Probolinggo, dan lain lain.

\section{Kesimpulan}

Dalam perkembangannya eksistensi pesantren menjadi sesuatu yang berpengaruh besar terhadap pembentukan manusia yang aqiilin, muttaqin, dan Sholihin. Hal tersebut menjadi indicator pesantren bahwa pada hakikatnya pesantren bukanlah sarana peribadatan namun juga sebagai pencetak kader sumber daya manusia unggul dalam semua bidang ilmu, termasuk ilmu tentang berwirausaha. Salah satu bentuk usaha dalam pondok pesantren yang dapat terlihat eksistensinya ialah usaha home industri bakery di PP.Nurul Jadid wilayah Al-Mawaddah.

Usaha home industri ialah usaha ekonomi produktif yang berdiri sendiri, yang dikelolah oleh perorangan atau badan usaha yang bukan milik anak perusahaan atau cabang perusahaan, dikuasai, atau merupakan bagian baik langsung maupun secara tidak langsung dari usaha menengah atau usaha besar. Pada sisi lain, home industri yang terjadi pada pesantren lama yang muncul dengan "wajah baru", "elitis", "modern", juga mempunyai public-trust yang akuntabel. Muncul pula, beberapa keunikan home industri yang terjadi pada pesantren baru yang menampilkan orientasi juga pencitraan baru (image building). Keduanya mempunyai segmen pasar masyarakat (stakeholder) yang berbeda, namun jika keduanya bersinergi, maka pada ujungnya akan mampu memberikan kontribusi real dan signifikan pada peningkatan kualitas hidup masyarakat muslim dan bangsa Indonesia.

Wilayah Al-Mawaddah juga memiliki wadah penyaluran bakat berwirausaha, dalam hal ini terbungkus pada title sumber daya insani (SDI) atau lebih akrab dikenal dengan sebutan "santriprenuership". Dalam pengembangan santripreneur pesantren menyediakan ladang usaha berupa usaha roti, usaha kuliner, air dan sebagainya. Bermodal keinginan wilayah Almawaddah tersebut berlanjut ke realisasi usaha memproduksi roti. Dalam hal ini, pelaksanaan pengkaderan ekonomi terhadap santri di pondok pesantren ini nantinya diharapkan akan melahirkan out put santri yang memiliki daya kompetisi yang tinggi. Dengan bekal keterampilan yang diberikan, diharapkan mereka akan lebih produktif dan mampu bersaing didunia kerja. Dengan ini, pesantren mengambil langkah tepat karena dapat membuktikan bahwa pondok pesantren terbilang sebagai salah satu lembaga pendidikan yang berkualitas dan kompetitif.

\section{Daftar Pustaka}

Abdul Basyit, "Pembaharuan Model Pesantren: Respon Terhadap Modernitas, "KORDINAT XVI, no. 2 (2017), hIm. 294-324.

Haikal Ulum, Bisnis Home Industri Soe Ha Corp dalam Perpektif Mazhab Syafi'I, 13

Hasil wawancara tentang Home Industri Bakery Berbasis Kader di Wilayah Al-mawaddah, kepada pengurus wilayah Al-mawaddah tgl 25 januari 2020.

Ni Putu Kiki Vrashinta Dewi, Ni Luh Putu Wrasiati, I Ketut Satriawan, STRATEGI PENGEMBANGAN USAHA PRODUKSI ROTI BALI KENCANA BAKERY, DENPASAR, Jurnal REKAYASA DAN MANAJEMEN AGROINDUSTRI, Vol. 3. No. 4. Desember $2015(41-50)$

Mas'ud A. (2002). Dinamika Pesantren dan Madrasah. Yogyakarta: Pustaka Pelajar.

Moh. Idil Ghufron, Moch. Rahmadtullah, PERAN EKONOMI KREATIF SEBAGAI SOLUSI MENGATASI PENGANGGURAN, Jurnal Ilmiah FE-UMM, Vol. 13 (2019) No. 1

Muhammad Hasyim Ibnu Abbas, Hadi Sumarsono, Yogi Dwi Satrio, Magistyo Purboyo Priambodo, PEMBERDAYAAN SANTRI PONDOK PESANTREN ANWARUL HUDA 
DI BIDANG EKONOMI KREATIF, Prosiding SENADIMAS Ke-4, Tahun 2019

Ririn Noviyant., Peran Ekonomi Kreatif Terhadap Pengembangan Jiwa Entrepreneurship di Lingkungan Pesantren: Studi Kasus di Pondok Modern Darussalam Gontor Putri 1. Jurnal Penelitian Ilmiah Intaj (2017) 1 : 77-99

Saifuddin Zuhri. ANALISIS PENGEMBANGAN USAHA KECIL HOME INDUSTRI SANGKAR AYAM DALAM RANGKA PENGENTASAN KEMISKINAN. Jurnal Manajemen dan Akuntansi. Volume 2, Nomor 3, Desember 2013.
SEKILAS TENTANG WILAYAH AL - MAWADDAH. Syahrul Falah, Irham Zaki. PEMBERDAYAAN EKONOMI MASYARAKAT ALA PONDOK PESANTRENDI KELURAHAN KEJAWAN PUTIH TAMBAK SURABAYA. Jurnal Ekonomi Syariah Teori dan Terapan Vol. 4 No. 4 April 2017: 340-352;

Ugin Lugina, PENGEMBANGAN EKONOMI PONDOK PESANTREN DI JAWA BARAT, Jurnal Pendidikan dan Studi Islam Volume. 4, Number. 1, December 2017 